Journal of Social Sciences 5(2): 139-145, 2009

ISSN 1549-3652

(C) 2009 Science Publications

\title{
US Foreign Policy and Aid to the Peace Corps
}

\author{
Donald D.A. Schaefer \\ Texas Tech University, 303 Detroit Avenue, Apt. 216, Lubbock, TX 79415, USA
}

\begin{abstract}
Problem statement: This study examined foreign aid as administered by the US Agency for International Development (USAID) through four presidencies, beginning with the Reagan era. Aid dispensed to the Peace Corps for humanitarian purposes was the major focus of the investigation. The research proposed that such aid should continue under the President Barack Obama administration. Approach: The approach taken used both qualitative analyses of the four administrations along with quantitative analyses of the data from USAID. Results: The findings indicated that, while many forms of economic and military assistance had been both used and abused throughout much of American history, the Peace Corps created under President John F. Kennedy presented an exception. However, the Peace Corps had received both benefit and harm as a beneficiary of US foreign aid due to fluctuating economic realities associated with the federal budget. President Reagan was a strong supporter of the Peace Corps; yet, it was "under his watch" that the Gramm-Rudman-Hollings Deficit Reduction Act of 1985 was passed, which negatively influenced nearly all forms of economic and military assistance distributed through USAID. Starting with President Clinton's second term funding for USAID dramatically increased. Conclusion: The Peace Corps was not immune to the adverse effects, but funding also increased under President Clinton. From this time onward, the Peace Corps has enjoyed a high level of political and financial support, a scenario that deserves to be continued under President Obama. This study can help future analyses of the US presidential responses to the giving of assistance to the Peace Corps.
\end{abstract}

Key words: US foreign policy, peace corps, US agency for international development, foreign economic assistance, human rights

\section{INTRODUCTION}

Foreign economic assistance is one of the most difficult subjects of debate between the US congress and president. Few other issues have generated the number of hearings or levels of praise and anguish as this government component. From assistance to Israel and Egypt to the economic support of South Africa and the former Zaire, myriad opinions have been expressed with regard to the proper direction for such American foreign policy. This study will first address the general changes in the direction of foreign economic assistance from the Reagan administration to through the second George W. Bush administration. It will then argue that the same direction of change to the overall budget and direction of foreign economic assistance are closely related to the overall budget and direction of the Peace Corps under the same administrations. The research begins with one of the most influential presidents in recent history-someone who stood behind the Peace Corps throughout his presidency.

Ronald Reagan: One individual in recent history stands out for his ability to institute positive change that not only produced national effects, but a global impact over nearly 2.5 decades-Ronald Reagan. The major turning point with regard to the direction of the US aid budget began with Carter. During the final year of his presidency, Afghanistan was invaded by the former Soviet Union. The Carter administration's increase in military assistance came too late and he was criticized as "soft" on defense spending. Stubbing ${ }^{[20]}$ stated, "As a candidate in 1980, Ronald Reagan campaigned hard on the perception of a vastly weakened America. He scored well with blanket assertions of US military inadequacy, caused by conciliatory detente policies and underfunded defense budgets of the 1970s. He portrayed President Carter as "soft on defense" (851).

Reagan was elected partially due to the "window of opportunity" presented by the Soviet military threat left unaddressed by the Carter administration with massive cuts in the defense budget. One of many Reagan goals was a safer world through facilitating defeat of what he considered Soviet expansionism. Foreign assistance played an important role toward this end. The Reagan administration introduced an increase in military and economic assistance via the US Agency 
for International Development (USAID) that would continue until the introduction of the Gramm-RudmanHollings Deficit Reduction Act (GRHDRA) during 1985. As Fig. 1 shows, this equated to a large increase in the aid budget when Reagan entered office ${ }^{[21]}$.

From 1981 through 1985, the Reagan administration transformed the focus of aid from a humanitarian grounding to a "pawn" of national security ${ }^{[18]}$. Figure 2 shows the changes that took place during this period. Specifically, the dramatic rise in assistance to other countries is clearly evident in the mean per capita spending on foreign aid. The graph not only depicts the dramatic rise in assistance, but also the many changes during four government administrations.

What subsequently transpired, however, from 1981 forward, was a series of actions that can be best described as a "tug-of-war" between Reagan and the US congress that included a gradual takeover of the foreign aid budget via "earmarks." Earmarking can be described as a form of direct allocation, which allows members of Congress to set aside specific funds solely for designated purposes. This process of earmarking became increasingly prevalent with each passing year.

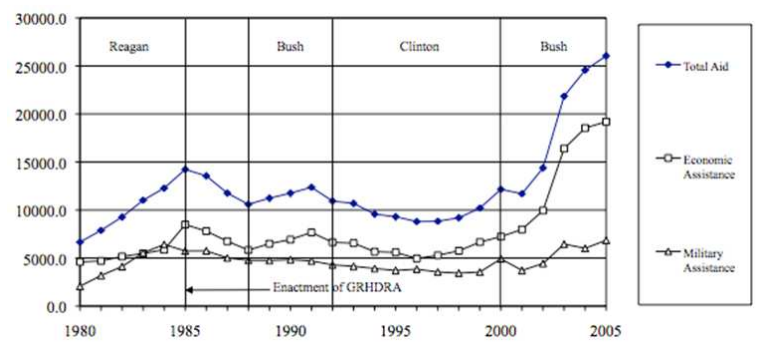

Fig. 1: Federal budget allocations from the US agency for international development 2007 to all countries in millions of US dollars. GRHDRA = Gramm-Rudman-Hollings Deficit Reduction Act ${ }^{[21]}$

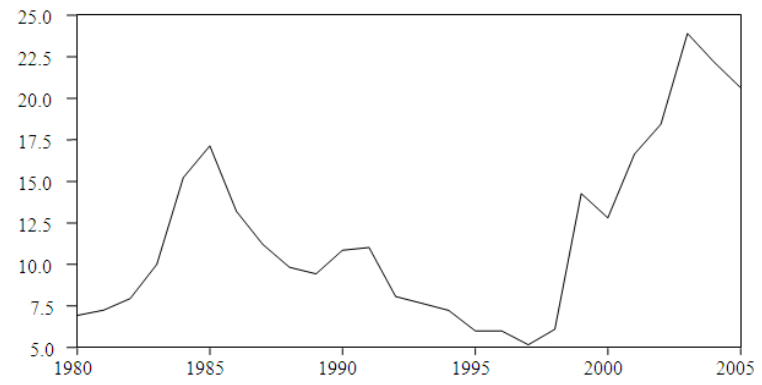

Fig. 2: Mean of per capita economic aid allocated by the US Agency for International Development for all countries in US dollars ${ }^{[21,27]}$
The problem of the US budget deficit became a clear reality after the concurrently increased military budget and tax cuts. Reagan ${ }^{[15]}$ strongly supported major increases in defense spending, noting, "I believe another reason the American people voted me in was to rebuild our nation's military, which was in a state of disrepair and neglect. For too long, our leaders had thought we could have a strong military on the cheap and so it was the military budget that was always cut" (127). In response to criticism of his tax cuts, Reagan ${ }^{[16]}$ stated, "The reality is that the effect of the tax cuts enacted in 1981 was mainly to hold tax rates even, to keep the hard-pressed American taxpayer from being bled even drier through further hikes and the bracket creep caused by inflation" (216). The final collective outcome of both scenarios was a markedly increased national debt, which spurred budget constraints forcing the attention of both congress and future administrations. The national debt continued to be a major problem of concern for future administrations (Fig. 3) ${ }^{[22,23]}$; however, Reagan was the first president to institute a possible solution through the GRHDRA.

The GRHDRA was mandated during 1985 and proposed a balanced budget over a six-year period, which was a major priority for Reagan and subsequent administrations. During 1987, Reagan ${ }^{[14]}$ argued that, if only Congress had instituted the budget cuts he had proposed earlier, the problem would not have reached such a magnitude. He explained:

To reduce the national debt, of course, requires balancing the budget and stopping the deficit spending that is going on. We have been trying to do that with the budgets that we've submitted over these last few years. When I hear some of our opponents complaining that I am responsible for the present deficits, I get a little annoyed, because if we had been given the budget that I asked for in 1982, the cumulative deficits through 1986 would be $\$ 207$ billion less than they turned out to be $^{[14]}$.

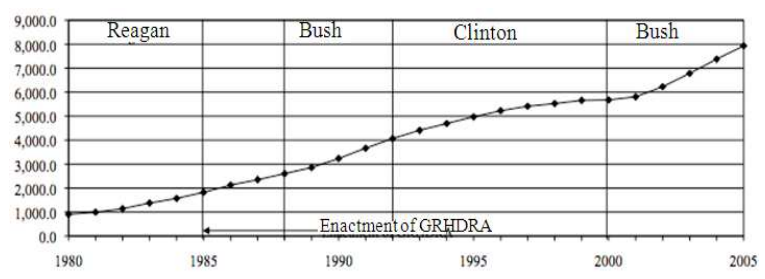

Fig. 3: Historical record of the outstanding national debt of the United States in billions of US dollars $^{[22,23]}$ 


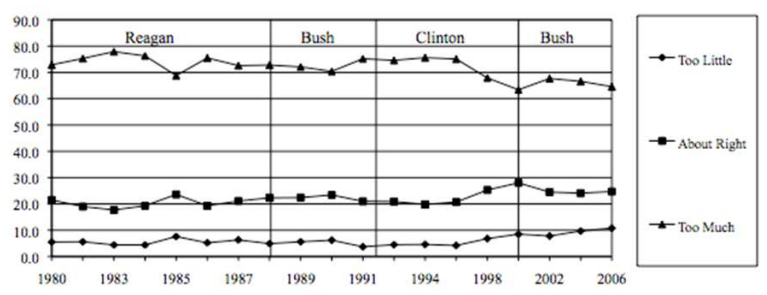

Fig. 4: Public opinion on assistance to other countries $^{[19]}$

Throughout his term in office, Reagan ${ }^{[16]}$ argued that cuts in federal taxes were needed (216), as was increased military spending ${ }^{[15]}$. Both caused major additions to the budget while limiting the funds to cover the increase in expenditures. Deibel ${ }^{[9]}$ concluded, "The most conservative president in the postwar era, one who made balancing the budget one of the three promises as he sought the presidency (the other two were in lower taxes and restoration of American military power), was far and away the biggest deficit spender in American history, tripling the national debt and turning the United States from the world's biggest creditor into the world's biggest debtor" (34-5). The impact of the Reagan years extended through the three subsequent presidencies.

The national deficit rose an astounding $\$ 300+$ billion with each passing year since the Reagan administration, which has had not only a tremendous national impact ${ }^{[13]}$, but has also presented a significant impact in the foreign-affairs budget. With social programs reduced each year, it was difficult for many US citizens to understand how Congress could possibly spend more outside our borders with millions of suffering Americans at home. Thus, foreign assistance became a common target; although, foreign aid has never been a popular program. This lack of support is partially due to the relative lack of persistence on the part of the US government to inform the American public on the merits of foreign aid ${ }^{[11]}$. Kingdon ${ }^{[10]}$ noted, "As one Great Plains Republican put it, 'There's just nobody who has ever approached me personally to argue in favor of foreign aid. I've heard plenty against it, but I don't think anybody has ever asked me to vote for it"" (151).

Figure 4 shows the level of support for assistance to other countries, as reported in a study conducted by Smith $^{[19]}$. Figure 4 graphs those respondents who answered affirmatively to a question related to whether foreign aid should be provided to other countries by the United States. According to T. W. Smith (pers. comm., July 17, 2008), the data averages results from two questions: (1) "Are we spending too much, too little, or about the right amount on foreign aid?" and (2) "Are we spending too much money, too little money, or about the right amount of money on assistance to other countries?" (16). This method was used due to the limited statistical difference in the results between the two questions presented. With foreign assistance so unpopular within the United States, it is clear why it was targeted for reduction following implementation of the GRHDRA. The basic issue, however, was the many changes to the military and tax structure that were simply too difficult to discontinue. From implementation of the GRHDRA forward, members of both the White House and Congress attempted to find ways to reduce the national budget. Foreign assistance and welfare became common "scapegoats" for each representative in Congress as they attempted to "solve" the problem.

During February 1986, Jeane Kirkpatrick-Reagan's ambassador to the United Nations-contributed her own views:

Why, in this year of zillion-dollar debt, big deficits, deep domestic spending cuts and Gramm-Rudman, has the Department of State proposed to increase foreign assistance by a billion dollars? Secretary of State George Shultz tells us there is no problem that his budget request is 'fully consistent with the targets on the deficit set out by Gramm-Rudman,' but it is hard to follow his logic...Foreign aid is one of the least loved, most vulnerable expenditures of any US administration ${ }^{[26]}$.

Congress took the initiative with the GRHDRA and used the process of earmarking to force changes, blocking the ability of each administration to decide the direction of foreign assistance. By the time that Reagan departed from office, the takeover of the foreign-aid budget by members of Congress was nearly complete and this process would only get worse.

George HW Bush: Secretary of State Baker of the George HW Bush administration argued against earmarking throughout his term in office. He called for the elimination of all earmarks, explaining, "Our position is if we can increase the amount of foreign assistance, fine and we have asked you for some more in our budget-a nine percent increase this year. If you can't do that, that's fine... But in the absence of that, at the very least, take what you do have and don't earmark 95 percent of that. Let us respond to some of these changing priorities" $(86-87)^{[24]}$. Yet, few were willing to alter the process of earmarking that consumed nearly the entire budget.

The cuts to foreign economic assistance stopped for only a short period of time at the end of the Cold War. As Bush noted,

Since World War II, foreign assistance often served as a weapon in the Cold War. Obviously, we will still use critical foreign assistance funds to meet 
legitimate security needs. . . . But foreign aid as we've known it needs to be transformed. The notion of the handout to less developed countries needs to give way to cooperation in mutually productive economic relationships... To move from aid, what I would call aid dependency, to economic partnership, we propose to alter fundamentally the focus of US assistance programs to building strong, independent economies that can become contributors to a healthy, growing global economy ${ }^{[3]}$.

Foreign aid was a significant consideration in many of the foreign-policy goals established by George H. W. Bush. Yet, by the end of his administration during 1993, the cuts continued, as they would through much of the Clinton second term.

Bill Clinton: The administrator for the USAID Agency during the Clinton administration, frustrated over the need to cut assistance while maintaining the earmarks, stated, "The pie is getting dangerously smaller and as the pie gets smaller, they [the representatives] fight ever harder for their piece, for their earmark" (47) ${ }^{[25]}$. The fight over earmarks grew increasingly fierce as remaining funds dwindled. Cuts to foreign assistance continued well into the Clinton administration before rebounding during 1998 when Clinton asked, "Why do we spend so little on foreign aid on the poor now? Because they don't have any votes in our country and because we don't think enough about it. I mean, every year my foreign aid budget is cut back" ${ }^{,[]}$. During this same time period, American attitudes toward foreign aid changed for the better. The clearest example is the greater number of Americans who supported aid to other countries compared to previous years (Fig. 4). This change continued well into the George W. Bush administration.

George W Bush: George W Bush supported the continued increase in foreign aid throughout much of his administration. He noted, "The evidence shows that where nations adopt sound policies, a dollar of foreign aid attracts \$2 of private investment. And when development aid rewards reform and responsibility, it lifts almost 4 times as many people out of poverty, compared to the old approach of writing checks without regard to results" (2002). This administration continued to push for additional funding for foreign assistance. Bush $^{[5]}$ has expressed his hope to reward those countries that become more democratic under the Millennium Challenge Account, stating, "We will reward nations that have more open markets and sustainable budget policies, nations where people can start and operate a small business without running the gauntlets of bureaucracy and bribery." Throughout his term in office, foreign aid continued to increase.

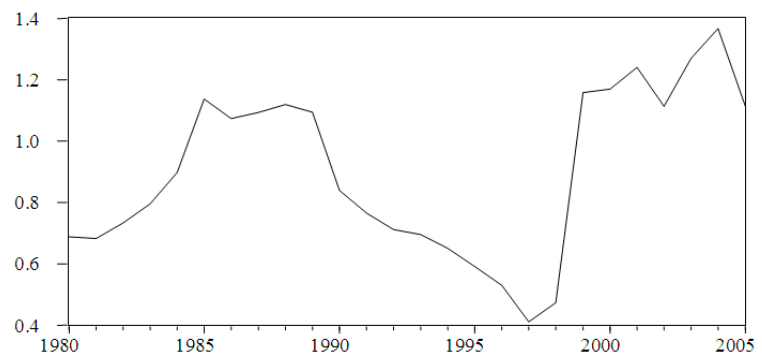

Fig. 5: Mean of per capita Peace Corps allocations by the US agency for international development for all countries in US dollars ${ }^{[21,27]}$

In summary, economic aid to foreign countries has been an area of struggle for the presidential administrations from Reagan to date. It is an area with minimal support from the American public, although that support has clearly increased since 1988. Reagan changed the direction of foreign aid from humanitarianbased assistance to a component of national security. Yet, many related changes were thwarted by the GRHDRA and the necessity to address budgetary matters. The Cold War facilitated funding for foreign assistance; however, it was not until 1988 and the Clinton administration that the foreign-aid budget began to increase. This rise in dollars earmarked for foreign assistance continued through the George W. Bush administrations.

Foreign assistance to the peace corps: Foreign aid has served as an important policy tool for the past four administrations. Yet aid to the Peace Corps has, in many ways, mirrored the economic assistance disbursed since the 1980s. A simple correlation test, using these two variables of total economic assistance per capita from the USAID and total Peace Corps assistance per capita from the USAID, resulted in a correlation of 0.48 with 1,575 observations. Clearly, a reasonable level of comparison exists between these two variables. Figure 5 shows the many changes in federal budget allocation for the Peace Corps. The comparison shown in Fig. 2 indicates the close relationship between the budgets of the USAID for economic assistance and the Peace Corps.

Reagan did desire to maintain the Peace Corps within much of the world, including Africa. For him, Africa was an opportunity to make a significant contribution in this part of the world while also providing an opportunity for volunteers to pass on their American values and democratic ideas. The overall plan for these groups of primarily young people did no major harm and may have actually helped a number of recipients. However, the major focus of the Peace 
Corps is on regional problems, helping one small village at a time. As Reagan ${ }^{[16]}$ noted, "From thousands answering Peace Corps appeals to help boost food production in Africa, to millions volunteering time, corporations adopting schools and communities pulling together to help the neediest among us at home, we have refound our values" (277). Many of the Reagan foreign policies involving Africa have been criticized, but this is one area that even the strongest of critics seem to agree that good was rendered. As Rotberg ${ }^{[17]}$ noted:

- Under Loret Ruppe, a skillful, broad-minded political appointee from Michigan, the Peace Corps has always done best. It fostered people-to-people contact, introducing young and older Americans to the life of inner Africa as well as its national capitals. Those Americans-approximately 3,000 in twenty-seven countries-helped Africans learn to farm fish, to husband their dwindling supplies of wood fuel and to learn English, mathematics, science, bee-keeping and other skills... Most of all, they were there, helping Africans learn to...help themselves...Whatever the Reagan era accomplished and failed to accomplish, it at least sustained the Peace Corps. (136-37)

For Reagan, as with the next three administrations that followed him, the Peace Corps proved to be an effective tool for peace and to project a positive image of the United States with the rest of the world. This one agency, more than any other, managed to capture the hearts of US presidents from Reagan through the George W. Bush administration, as it did with many US citizens and people from across the globe. The elder Bush $^{[2]}$ declared that he was "strongly in favor of the Peace Corps" and, as Reagan had before him, he protected the Peace Corps from government intervention. ${ }^{[2]}$ However, the level of funding for this organization was indeed cut in many areas during his time in office, reflecting both budgetary realities and the fall of the Soviet Union (Fig. 5). Yet, through all the struggles, Bush ${ }^{[4]}$ continued to advocate for additional funding for the Peace Corps. He stated, "Foreign aidit's always been unpopular. There's always a guy that says, 'Don't do that abroad. Do it all at home.' And that's a mood out there in this country. But it is in our interests, humanitarian interest, to help people abroad. It's the United States that always has taken the lead. As long as I'm President, we'll continue to take the lead'.

Foreign assistance was popular with Bush from 1989 through 1993; he wielded it as a major foreignpolicy tool in Latin America, the Middle East, Africa and Europe. However, as Reagan before him, he was forced to constantly negotiate between the demands of a dramatically altered world landscape and domestic priorities that included a dramatically rising national debt. The Clinton administration also supported continued funding for the Peace Corps, perhaps because it had the potential to merge both domestic and foreign affairs in a way few other issues could. It was also during the Clinton administration that funding for the Peace Corps increased dramatically (Fig. 5). Clinton personally invested in the Peace Corps, as had both Reagan and the elder Bush. During 1996, at a 35th anniversary celebration for the Peace Corps, Clinton ${ }^{[7]}$ stated:

- The Peace Corps symbolized everything that inspired my generation to service. It was based on a simple yet powerful idea, that none of us alone will ever be as strong as we can all be if we'll all work together. None of us can reach our fullest potential while others are left behind. Community counts and every member of our community matters at home and on this increasingly small planet we share... So let us always remember that the truest measure of the Peace Corps' greatness has been more than its impact on development. The real gift of the Peace Corps is the gift of the human heart, pulsing with the spirit of civic responsibility that is the core of America's character. (930-31)

Foreign assistance in general and the Peace Corps in particular, benefited Clinton; however, during the course of his administration, such programs held the power to both hurt and help him. After the Cold War, the need for continued economic and military aid was questioned by both the American public and Congress. Clinton $^{[6]}$ argued its merits, equating a refusal to contribute to increased isolationism. The subsequent Bush administration also viewed the Peace Corps in a very positive light and sought to continue high funding levels. Bush stated on April 29, 2008.

Forty-seven years ago, President John F. Kennedy, in the Rose Garden, sent the first team of Peace Corps volunteers to Africa. And in the intervening years, more than 190,000 Peace Corps volunteers have carried our country's great spirit of generosity and compassion throughout the world...Laura and I met with Peace Corps volunteers in Ghana recently and they are some kind of fired up [Laughter]. And a matter of fact, it is exciting to be with those good souls who are motivated to put-to go help and in so doing, it really is the best foreign policy America could possibly have ${ }^{[1]}$. 
Foreign assistance to the Peace Corps was, for Bush, as with the previous three administrations, very important. It is an area he has continued to vigorously support.

From Reagan through the following three administrations, foreign economic assistance, specifically the Peace Corps, has played a role in foreign policy. Yet, giving to the Peace Corps was not as politically motivated as other forms of assistance; most notably, military assistance. Consequently, the continued aid to this organization is not a surprise.

\section{CONCLUSION}

There has been clear desire on the part of four administrations from Reagan through the George W. Bush administration to assist the Peace Corps. Yet, as has been clearly demonstrated in this current study, such effort toward this end has been hampered through the enactment of the GRHDRA, resulting in a gradual decline in assistance to the organization from 1985 through 1997. However, support for this area of funding has never been lacking. While funding clearly increased following the end of the Cold War, it continued its fall until the second term of the Clinton administration. From 1998 forward, however, assistance to the Peace Corps again increased and that support has continued through the George W. Bush administration. According to the Peace Corps ${ }^{[12]}$, “Today's...Peace Corps Volunteers continue to help countless individuals who want to build a better life for themselves, their children and their communities."

\section{REFERENCES}

1. Bush, G.W., 2008. Remarks on national volunteer week. http://www.accessmylibrary.com/coms2/summary_ 0286-34385303_ITM

2. Bush, G.H.W., 1990. Remarks and a question-andanswer session at a White House briefing for members of the board of directors of the National Newspaper Association.

3. Bush, G.H.W., 1992. Address to the United Nations General Assembly in New York City. http://www.encyclopedia.com/doc/1G1-93612108.html

4. Bush, G.H.W., 1992. Remarks and a question-andanswer session with the American legion boys nation. http://bulk.resource.org/gpo.gov/papers/1992/1992 _vol1_1138.pd

5. Bush, G.W., 2002. Remarks at the Inter-American Development Bank.

http://connection.ebscohost.com/content/article/10 23897721.html;jsessionid=790635BF1D3B0D766 0875612661FA77C.ehctc1
6. Clinton Bill, 1996. The president's news conference with President Chirac of France. http://connection.ebscohost.com/content/article/10 28843413.html;jsessionid=E02828FA44814DB5A E208BEDBC7AB4B5.ehctc1

7. Clinton Bill, 1997. Remarks on the 35 anniversary of the peace corps.

http://bulk.resource.org/gpo.gov/papers/1996/1996 _vol1_930.pdf

8. Clinton Bill, 1998. Remarks at strengthening democracy in the global economy: An opening dialogue in New York City. http://connection.ebscohost.com/content/article/10 32856460.html;jsessionid=53E63554A193A74F86 AD5825BD478DCC.ehctc1

9. Deibel, T.L., 1989. Reagan's mixed legacy. Foreign Policy 75: 34-55. http://www.foreignpolicy.com/Ning/archive/archiv e/075/REAGANS_MIXED_LEGACY.PDF

10. Kingdon, J.W., 1992. Congressmen's Voting Decisions. 3rd Edn., University of Michigan Press, Ann Arbor, MI., pp: 1-346.

11. Carol, L. and A.V. Dusen, 2005. Organizing US Foreign Aid: Confronting the Challenges of the 21st Century. 1st Edn., Brookings Institution Press, Washington, DC., ISBN: 10: 0815751133 pp: 1-78.

12. Peace Corps, 2008. About the Peace Corps. http://www.peacecorps.gov/index.cfm?shell=learn. whatispc

13. Peterson, P.G., 1993. Facing Up: How to Rescue the Economy from Crushing Debt and Restore the American Dream. 1st Edn., Simon and Schuster, New York, pp: 1-432.

14. Reagan Ronald, 1987. Remarks and a questionand-answer session at a luncheon in Los Angeles, California.

15. Reagan, R., 1989. Remarks at the recommissioning of the USS New Jersey. Proceeding of the Speaking My Mind: Selected Speeches, Dec. 28-28, Long Beach, California, pp: 127-33.

16. Reagan, R., 1993. State of the Union Address: January 26, 1982. In: Actor, Ideologue, Politician: The Public Speeches of Ronald Reagan, Davis W.H. and A. Kiewe (Ed.). Greenwood Press, Westport, CT., pp: 195-98.

17. Rotberg, R.I., 1990. The Reagan Era in Africa. In: Reagan and the World, David, E.K. (Ed.). Greenwood Press, New York, pp: 119-39.

18. Schaefer, Donald David Arthur, 1999. US Foreign Assistance and the Change from Economic to Security-Based Aid: Reagan through Clinton. Michigan, (PS), DA 9929945. 
19. Smith, T.W., 2007. Trends in national spending priorities, 1973-2006.

www.norc.org/NR/rdonlyres/32D06C9A-751B-

45EB-AD7E-

D51019DD7298/0/TrendsinNationalSpendingPrior ities.pdf

20. Stubbing, R., 1985. The defense program: Buildup or binge? Foreign Affairs, 63: 848-72. http://www.foreignaffairs.com/articles/39632/richa rd-stubbing/the-defense-program-buildup-or-binge

21. US Agency for International Development, 2007. US Overseas Loans and Grants and Assistance from International Organizations, 1945-2005 (Cong-R-0105). 1st Edn., US Agency for International Development, Washington, DC., USA., pp: 1-231.

22. US Department of the Treasury, 1999. Historical debt outstanding-annual, 1950-1999. http://www.treasurydirect.gov/govt/reports/pd/histd ebt/histdebt_histo4.htm

23. US Department of the Treasury, 2007. Historical debt outstanding-annual 2000-2007. http://www.treasurydirect.gov/govt/reports/pd/histd ebt/histdebt_histo5.htm
24. US House Committee on Foreign Affairs, 1990. Authorization Request for Foreign Assistance, The Department of State and USIA for Fiscal Years 1990-91: Hearings before the Committee on Foreign Affairs, House of Representatives, One Hundred 1st Congress, Second Session. http://nla.gov.au/nla.cat-vn4020003

25. US House Committee on Foreign Affairs, 1993. Foreign assistance legislation for fiscal year 1994: hearings and markup before the Committee on Foreign Affairs, House of Representatives, One Hundred 3rd Congress, First Session. http://www.archive.org/details/foreignassistanc06unit

26. US Senate Committee on the Budget, 1988. Concurrent resolution on the budget for FY87 hearings. Government Printing Office, Washington, DC. http://catalogue.nla.gov.au/Record/4000968

27. World Bank. 2007. "World Development Indicators on CD-ROM." World Bank CD-ROM. http://web.worldbank.org/WBSITE/EXTERNAL/ DATASTATISTICS/0,,contentMDK:21298138 pa gePK:64133150 piPK:64133175 theSitePK:2394 19,00.html 